В.С. Савельев, В.А. Петухов, Е.С. Ан [и др.] // «РМЖ». 2009. - №14. - Том 14. - С.881-890.

7. Справочник по лабораторным методам исследования // под ред. Л. А. Даниловой - СПб.: Питер, 2003. - 736 с.

8. European convention for the protection of vertebrate animals used for experimental and other scientific purposes. Council of Europe, Strasbourg, 1986. - 53 p.

9. Samim F. Erythema multiforme: a review of epidemiology, pathogenesis, clinical features, and treatment / F. Samim, A. Auluck, C. Zed, P. Williams // Dent Clin North Am. - 2013. Oct; - №57(4). - P. 583-96. doi: 10.1016/j.cden.2013.07.001.

\section{REFERENCES}

1. Alekseeva O.G., Dueva L.A. Allergija $k$ promyshlennym himicheskim soedinenijam [Allergy to industrial chemical compounds]. Izd. Medicina. Moskva;1978:271.

2. Arilin A.A. Immunologija (uchebnik) [Immunology (textbook)]. M.: Media; 2010:752.

3. Artamentova L.A., Utelevskaja O.M. Statistical methods in biology: textbook [for students of higher educational institutions]. Gorlovkal ChP «Vydavnyctvo «Lihtar»;2008:248.

4. Myhajlovs'ka N.S., Olijnyk T.V. Features monosporin activation and functional state of endothelium in patients with coronary artery disease associated with hypothyroidism. Problemy endokrynnoi' patologii'.2015;4:3742 .

5. Okrut I.E., Dautova D.A. Indicators of endothelial function in atherosclerosis. Innovacionnaja nauka. 2015;10$1: 217-218$.

6. Savel'ev V.S. Petuhov V.A. An E.S. Semenov Zh.S. Mironov A.V. Endothelial dysfunction in lipid distress syndrome and dysmetabolic effects of peritonitis. «RMZh». 2009;14(14):881-890.

7. Spravochnik po laboratornym metodam issledovanija [Reference book on laboratory research methods]. edited by L. A. Danilova. SPb.: Piter; 2003:736.

8. European convention for the protection of vertebrate animals used for experimental and other scientific purposes. Council of Europe, Strasbourg; 1986:53.

9. Samim F., Auluck A., Zed C., Williams P. Erythema multiforme: a review of epidemiology, pathogenesis, clinical features, and treatment. Dent Clin North Am. 2013 Oct;57(4):583-96. doi: 10.1016/j.cden.2013.07.001.

Поступила 12.04.20

УДК 616.311:579.23 - 036.632: 599.323.4

DOI https://doi.org/10.35220/2523-420X/2020.1.2

С.А. Шнайдер, д. мед. н., А.В. Маслов, к. мед. н., Е.К. Ткаченко, к. биол. н.

Государственное учреждение «Институт стоматологии и челюстно-лицевой хирургии Национальной академии медицинских наук Украины»

\title{
МОРФОЛОГИЧЕСКИЕ ИЗМЕНЕНИЯ В СЛИЗИСТОЙ ОБОЛОЧКЕ ПОЛОСТИ РТА КРЫС ПОД ДЕЙСТВИЕМ ДЛИТЕЛЬНОЙ НЕДОСТАТОЧНОСТИ РАСТИТЕЛЬНОЙ ПИЩИ
}

Цель. Изучение влияния хронической недостаточности растительных полифенолов в рачионе экспериментальных животных на морфологические изменения эпителия в слизистой оболочке полости рта крыс.

Материалы и методы. Опыт проведен на 14 бельх крысах-самках. Интактные животные содержались на стандартном рачионе вивария. Во 2-й группе крысы содержались на бесполифенольном рационе. Длительность эксперимента составила 70 дней.

Выводы. Впервые изучено значение алиментарных растительных полифенолов для морфофункиионального состояния слизистой оболочки полости рта. Установлено, что хроническое лишение крыс растительной пищи вызывало существенные нарушения в эпителиальном пласте слизистой оболочки полости рта.

Ключевые слова: эпителиоциты, алиментарная недостаточность растительных полифенолов, слизистая оболочка щеки, белье крысы. 


\section{С.А. Шнайдер, А.В. Маслов, Е.К. Ткаченко}

Державна установа «Інститут стоматології та щелепно-лицевої хірургії Національної академії медичних наук України»

\section{МОРФОЛОГІЧНІ ЗМІНИ В СЛИЗОВІЙ ОБОЛОНЦІ ПОРОЖНИНИ РОТА ЩУРІВ ПІД ДІЕЮ ТРИВАЛОЇ НЕДОСТАТНОСТІ РОСЛИННОЇ ЇЖІ}

Мета. Вивчення впливу хронічної недостатності рослинних поліфенолів в раціоні експериментальних тварин на морфологічні зміни епітелію в слизовій оболонці порожнини рота щурів.

Матеріали та методи. Дослід проведено на 14 білих щурах-самках. Інтактні тварини містилися на стандартному рачіоні віварію. У 2-й групі щури утримувалися на бесполіфенольном раиіоні. Тривалість експерименту склала 70 днів.

Висновки. Вперше вивчено значення аліментарних рослинних поліфенолів для морфофункиіонального стану слизової оболонки порожнини рота. Встановлено, що хронічне позбавлення щурів рослинної їжі викликало істотні порушення в епітеліальних шарі слизової оболонки порожнини рота.

Ключові слова: епітеліоцити, аліментарна недостатність рослинних поліфенолів, слизова оболонка щзоки, білі щури.

\section{S.A. Schnaider, A.V. Maslov, E.K. Tkachenko}

State Establishment "The Institute of Stomatology and Maxillo-Facial Surgery National Academy of Medical Science of Ukraine"

\section{MORPHOLOGICAL CHANGES IN THE MUCOUS MEMBRANE OF THE ORAL CAVITY OF RATS UNDER THE INFLUENCE OF PROLONGED INSUFFICIENCY OF PLANT FOOD}

The aim of the study. Study of the effect of chronic plant polyphenol insufficiency in the diet of experimental animals on morphological changes in the epithelium in the mucous membrane of the oral cavity of rats.

Materials and methods. The experiment was carried out on 14 white female rats. Intact animals were kept on a standard vivarium diet. In the 2 nd group, rats were kept on a polyphenolic diet. The duration of the experiment was 70 days.

Conclusions. The value of alimentary plant polyphenols for the morphofunctional state of the oral mucosa has been studied for the first time. It was established that chronic deprivation of rats with plant foods caused significant disturbances in the epithelial layer of the oral mucosa.

Key words: epithelial cells, alimentary insufficiency of plant polyphenols, mucous membrane of the cheek, white rats.

Эпителий слизистой оболочки полости рта испытывает воздействие различных факторов (токсиканты, стрессы, лекарственные ксенобиотики). Оптимальный уровень резистентности тканей ротовой полости к патогенным агентам в значительной степени зависит от потребления растительной пищи.

Полифенолы (ПФ) растительного происхождения (флавоноиды, фенольные кислоты и их производные) нормализуют системные и локальные регуляторные процессы.

Цель исследования. Изучение влияния хронической недостаточности растительных полифенолов в рационе экспериментальных животных на морфологические изменения эпителия в слизистой оболочке полости рта крыс.
Материалы и методы. Опыт был проведен на 14 белых крысах-самках по 7 особей в группе. Интактные животные содержались на стандартном рационе вивария. Во 2-й группе крысы содержались на рационе, лишенном растительных компонентов или бесполифенольном рационе (БПР) [1]. Экспериментальный БПР включал: непросеянную пшеничную муку - 30 \%, цельный молочный порошок - $30 \%$, крахмал - $20 \%$, сахар - $15 \%$, хлористый натрий - 1\%. Из рациона [1] была исключена мука люцерны, как содержащая растительные ПФ. Длительность эксперимента составила 70 дней.

По завершению эксперимента крыс умерщвляли путем тотального кровопускания из сердца под тиопенталовым наркозом (40 мг/кг). 
Слизистую оболочку щеки (СОЩ) иссекали, фиксировали в формалине и заключали в парафин. Срезы толщиной 6-8 мкм (тонкие использовали для фотометрии) окрашивали гематоксилином и эозином, пикрофуксином по Ван Гизону и толуидиновым синим [2]. Подсчет митозов эпителиоцитов проводили в базальном и шиповатом слоях слизистой оболочки щеки при увеличении $15 \times 40$. Митотический индекс (МИ) вычисляли, исходя из общего количества учтенных клеток (3000) и выражали в процентах. Двуядерные эпителиоциты определяли в шиповатом слое на ограниченной площади среза при таком же увеличении. Кариометрические исследования клеток шиповатого слоя осуществляли путем зарисовки ядер на листке бумаги с помощью рисовального аппарата при увеличении микроскопа $15 \times 90$. Объем ядра рассчитывали по формуле элипсоида вращения

$$
V=\frac{\pi}{\partial} \times d^{2} \cdot D,
$$

где: D- большой диаметр; d- малый диаметр. Полученные результаты выражали в мкм ${ }^{3}$, а также десятичных логарифмах для снятия асиммет- рии распределения, что необходимо для построения кариометрических кривых и статистического анализа. На зарисовках определяли средние межъядерные расстояния, полученные величины переводили в мкм. Последний параметр использовали в качестве критерия оценки размеров клеток $[3,4]$. Степень эрозирования эпителиального пласта учитывали с помощью шкалы микрометра при увеличении 8х20. Коэффициент эрозии эпителия (К эроз. эпит.) вычисляли по соотношению протяженности: эпителий поврежденный/эпителий исследованный в условных единицах (усл. ед.).

На зарисовках кровеносных сосудов микроциркуляторного русла (МЦР), выполненных при увеличении $15 \times 40$, точечным методом определяли удельную площадь стенки кровеносного сосуда с образующими ее клетками и удельную площадь его просвета. По соотношению площадь стенки/площадь просвета рассчитывали коэффициент стеноза сосудов (КСС).

Результаты опытов обрабатывали с помощью критерия $\mathrm{t}$ достоверности различий по Стьюденту.

Таблица 1

\section{Результаты кариометрии и интеркариометрии эпителиоцитов слизистой оболочки щеки крыс (M $\pm \mathrm{m} ; \mathrm{p})$}

\begin{tabular}{|l|c|c|c|}
\hline \multicolumn{1}{|c|}{ Группы животных } & Базалиоциты & Шиповатые клетки & $\begin{array}{c}\text { Средние межклеточные рас- } \\
\text { стояния } \\
\text { (мкм) }\end{array}$ \\
\cline { 1 - 3 } & Объем ядра в $\lg \left(\right.$ мкм $\left.^{3}\right)$ & Объем ядра в $\lg \left(\right.$ мкм $\left.^{3}\right)$ & $18,0 \pm 0,71$ \\
\hline \multirow{2}{*}{ БПР } & $1,83 \pm 0,026$ & $2,27 \pm 0,028$ & $13,5 \pm 0,54$ \\
& $1,75 \pm 0,028$ & $2,09 \pm 0,023$ & $\mathrm{p}=0,003$ \\
\hline
\end{tabular}

Пр имеч чн ие . в табл. 1-3 показатель достоверности р рассчитан относительно интактной группы.

Результаты исследований. Слизистая оболочка щеки интактных крыс имела обычное строение. Многослойный плоский ороговевающий эпителий чётко подразделялся на базальный и шиповатый слои клеток, которые переходили в роговой слой. Базалиоциты состояли из клеток двух типов с мелкими удлинёнными ядрами и крупным хроматином и с крупными округлыми светлыми ядрами и менее плотным хроматином. Средняя величина объёма ядра составляла $-\mathrm{lg}$ $1,83 \pm 0,026$ (табл. 1$)$.

Основные классы ядерных объёмов имели размеры: 50-63-79 мкм ${ }^{3}$ (1 тип базалиоцитов - 70 $\%$ от общего количества клеток) и 100-126-158 мкм $^{3}$ (2-ой тип базалиоцитов - $30 \%$ ). Сопоставление полученных результатов показало, что основные классы ядерных объёмов базалиоцитов второго типа в 2 раза больше клеток 1-го типа.
Шиповатый слой представлен клетками со светлой цитоплазмой и полиморфными светлыми ядрами: средний объём ядер в них $-\lg 2,27 \pm 0,028$ мкм $^{3}$, среднее межъядерное расстояние $-18,0 \pm$ 0,71 мкм (табл. 1). В поверхностных рядах шиповатого слоя наблюдалось увеличение зёрен кератогиалина - результат активной кератинизации. Количественные параметры пролиферативных процессов эпителиоцитов таковы: митотический индекс (МИ) составлял $1,5 \pm 0,22 \%$, количество двуядерных клеток - $15 \pm 1,1$ \% (табл. 2).

Собственная пластинка слизистой оболочки была представлена волокнистой соединительной тканью, содержащей клетки и межклеточные структуры. Основные встречающиеся виды клеток - фибробласты и гистиоциты. Тучные клетки, плазмоциты, макрофаги и лейкоциты встречались в единичных экземплярах. Слизистая 
оболочка была обильно васкуляризована. Кровеносные сосуды МЦР имели типичное строение. Объёмная плотность (плотность упаковки) сосу- дов МЦР составляла 12,8 $\pm 0,6$ \% в тест-объёме; коэффициент сохранения просвета сосудов $\left(\mathrm{K}_{\text {спс }}\right)$ $-0,57 \pm 0,03$ (табл. 3).

Таблица 2

\section{Соотношение количества митозов и двуядерных клеток в эпителии слизистой оболочки щеки} крыс $(\mathrm{M} \pm \mathbf{m} ; \mathbf{p})$

\begin{tabular}{|l|c|c|}
\hline \multicolumn{1}{|c|}{ Группы животных } & $\begin{array}{c}\text { Митотический } \\
\text { индекс (МИ) } \\
(\%)\end{array}$ & $\begin{array}{c}\text { Количество двуядерных клеток } \\
(\%)\end{array}$ \\
\hline Интактная & $1,5 \pm 0,22$ & $15,0 \pm 1,1$ \\
\hline \multirow{2}{*}{ БПР } & $0,39 \pm 0,10$ & $23,0 \pm 1,4$ \\
& $\mathrm{p}=0,01$ & $\mathrm{p}=0,006$ \\
\hline
\end{tabular}

Таблица 3

\section{Состояние кровеносных сосудов микроциркуляторного русла слизистой оболочки щеки крыс} $(\mathbf{M} \pm \mathbf{m} ; \mathbf{p})$

\begin{tabular}{|l|c|c|}
\hline \multicolumn{1}{|c|}{ Группы животных } & $\begin{array}{c}\text { Плотность упаковки сосудов } \\
(\%)\end{array}$ & $\begin{array}{c}\text { Коэффициент сохранения просвета сосудов } \\
\mathrm{K}_{\mathrm{C \Pi C}}\end{array}$ \\
\hline Интактная & $12,8 \pm 0,60$ & $0,57 \pm 0,03$ \\
\hline \multirow{2}{*}{ БПР } & $8,9 \pm 0,50$ & $0,48 \pm 0,03$ \\
& $\mathrm{p}=0,004$ & $\mathrm{p}=0,07$ \\
\hline
\end{tabular}

В группе крыс, содержащихся на бесполифенольном рационе (БПР), эпителий слизистой оболочки щеки отличался некоторой неоднородностью по толщине. В нём обнаруживались очажки гиперкератоза, паракератоза и акантоза шиповатого слоя. В то же время большая часть эпителиального пласта имела обычное строение и толщину. Папилломатозные структуры в эпителии встречались в виде единичных экземпляров. На границе с ороговевшими клетками возникали небольшие очаги гидропически изменённых эпителиоцитов. Они подвергались деструкции и превращались в пузырьки, однако существенных повреждений эпителия выявлено не было.

Рацион, лишенный растительных полифенолов вызвал на поверхности эпителиального пласта небольшие эрозии рогового слоя. Базалиоциты, подобно таковым у интактных крыс, состояли из двух типов клеток с мелкими и крупными ядрами. Средний объём ядер базалиоцитов снижался в них на $4,4 \%(p=0,07)$, однако соотношение количества типов названных клеток существенно не отличалось от данных интактной группы (табл. 2). Среднее межъядерное расстояние клеток снизилось под действием рациона на $25 \%$ ( $\mathrm{p}=0,003)$, объем ядер шиповатого слоя снизился на $8 \%$ ( $\mathrm{p}=0,004$; табл. 1$)$.

Под действием рациона резко изменились показатели пролиферативных процессов в слизистой оболочке щеки. Митотическая активность клеток снизилась на $74 \%(\mathrm{p}=0,01)$; количество двуядерных эпителиоцитов при этом увеличилось на $53 \%(\mathrm{p}=0,006)$ по сравнению с данными интактных групп (табл. 2). 7 \% делящихся митозом клеток, имели атипичную форму, ассиметричные митозы.

В соединительной ткани собственной пластинки был умеренно выражен отёк коллагеновых волокон и межклеточного вещества. В кровеносных сосудах МЦР выявлено набухание эндотелиоцитов. Показатели состояния микроцирляторного русла изменились в сторону уменьшения: $\mathrm{K}_{\text {спс }}$ на $16 \%$ (тенденция, $\mathrm{p}=0,07$ ), а плотность упаковки сосудов снизилась на $30 \%$ $(\mathrm{p}=0,004$; табл. 3$)$.

Заключение. Впервые изучено значение алиментарных растительных полифенолов для морфофункционального состояния слизистой оболочки полости рта (СОПР). Установлено, что хроническое лишение крыс растительной пищи вызывало существенные нарушения в эпителиальном пласте слизистой оболочки полости рта. Эти нарушения могут быть сгруппированы следующим образом.

1. Нарушения клеточного деления. Проявлялись трехкратным снижением числа митозов в базальном слое, значительным возрастанием числа двуядерных клеток, т.е. числа незавершенных митозов (прерванных цитокинезов).

2. Нарушения дифференцировки клеток. Проявлялись в шиповатом слое уменьшением объема ядер, появлением очагов дискератоза и акантоза. 
3. Нарушения состояния микроциркуляторного русла, которые проявлялись умеренным отеком межклеточных структур, уменьшением плотности упаковки сосудов.

\section{Список литературы}

1. Прохончуков А. А. Руководство по терапевтической стоматологии / А. А. Прохончуков, Н. К. Жижина // Под ред. А. И. Евдокимова. - М.: Медицина, 1967 - 572 с.

2. Меркулов Г. А. Курс патологической техники / Г.А. Меркулов. - Л.: Ленгис, 1969. - 423 с.

3. Ташке К. Введение в количественную цитогистологическую морфологию / К. Ташке. - Изд. Акад. Соц. Республ. Румынии, 1980. - 191 с.

4. Автандилов Г. Г. Медицинская морфометрия / Г. Г. Автандилов. - М.: Медицина, 1990. - 384 с. - (Руководство).

\section{REFERENCES}

1. Prokhonchukov A. A., Zhizhina N.K. Rukovodstvo po terapevticheskoj stomatologii [Guide to therapeutic dentistry]. M.: Medicina, 1967:572.

2. Merkulov G. A. Kurs patologicheskoj tehniki [Course of pathological technology]. L.: Lengis, 1969:423.

3. Tashke K. Vvedenie $v$ kolichestvennuyu citogistologicheskuyu morfologiyu [Introduction to quantitative cytological histological morphology]. Izd. Akad. Soc. Respubl. Rumynii,, 1980:191.

4. Avtandilov G. G. Medicinskaya morfometriya [Medical morphometry] (Manual). M.: Medicina, 1990:384.

Поступила 22.04.20

УДК 616.314+616.716.8:611.08

DOI https://doi.org/10.35220/2523-420X/2020.1.3

В.С. Иванов, к.мед.н., С.А. Шнайдер, д.мед.н.,

О.В. Деньга, д.мед.н., Е.К. Ткаченко, к.биол.н.

Государственное учреждение «Институт стоматологии и челюстно-лицевой хирургии Национальной академии медицинских наук Украины»

\section{ВЛИЯНИЕ ГЛИЦИНА НА СОСТОЯНИЕ ЗУБОЧЕЛЮСТНОЙ СИСТЕМЫ И ТКАНЕЙ РОТОВОЙ ПОЛОСТИ КРЫС В УСЛОВИЯХ ДЕЙСТВИЯ ГИПОКСИИ И КАРИЕСОГЕННОГО РАЦИОНА}

Цель исследования. Изучение влияния экзогенного глицина на состояние зубочелюстной системь и тканей ротовой полости крыс в условиях воспроизведения гипоксии и кариесогенного рациона.

Материалы и методы. Эксперимент был проведен на 43 белых крысах линии Вистар, из которых 15 крыс-самок и 7 крыс-самиов, а также 21 самка 1-мес. возраста. У крыс-самок с 10 по 19 дни беременности в/брюшинно вводили нитрита натрия в дозе 10 мг/кг массы тела крыс. В продолжении 30 дней крысы также получали рег оs раствор комплекса «Глицин».

Результаты исследований. Глицин в условиях воспроизведения внутриутробной гипоксии и кариесогенного раичина проявил кариес-профилактическое, антиоксидантное, антигипоксическое и противовоспалительное действие.

Ключевые слова: тканевая внутриутробная гипоксия, кариесогенный рацион, глицин, антигипоксические эффекты, зубочелюстная система, крысы.

\section{В. С. Іванов, С. А. Шнайдер, О.В. Деньга, С. К. Ткаченко}

Державна установа «Інститут стоматології та щелепно-лицевої хірургії Національної академії медичних наук України»

\section{ВПЛИВ ГЛЦИНУ НА СТАН ЗУБОЩЕЛЕПНОЇ СИСТЕМИ І ТКАНИН РОТОВОЇ ПОРОЖНИНИ ЩУРІВ В УМОВАХ ДІЇ ГІПОКСІЇ ТА КАРЕСОГЕННОГО РАЦІОНУ}

Мета дослідження. Вивчення впливу екзогенного глічину на стан зубощелепної системи і тканин ротової порожнини щурів в умовах відтворення гіпоксії $і$ кариесогенного раціону.

Матеріали та методи. Експеримент був проведений на 43 білих щурах лінії Вістар, з яких 15 щурів-самок і 7 щурів-самиів, а також 21 самка 1-міс. віку. У щурів-самок з 10 по 19 дні вагітності в /брюшинно вводили нітрит натрію в дозі 10 мг / кг маси тіла щурів. У продовженні 30 днів щури також отримували рег оs розчин комплексу «Глічин». 